\title{
CORRIGENDUM
}

\section{PET imaging of dopamine-D2 receptor internalization in schizophrenia}

JJ Weinstein, E van de Giessen, RJ Rosengard, X Xu, N Ojeil, G Brucato, RB Gil, LS Kegeles, M Laruelle, M Slifstein and A Abi-Dargham

Molecular Psychiatry advance online publication, 25 July 2017; doi:10.1038/mp.2017.157

Correction to: Molecular Psychiatry advance online publication, 16 May 2017; doi: 10.1038/mp.2017.107

The authors' affiliations were presented incorrectly. The correct affiliations appear below:

JJ Weinstein ${ }^{1,2}$, E van de Giessen $^{3}$, RJ Rosengard ${ }^{4}, \mathrm{X} \mathrm{Xu}^{4}, \mathrm{~N}$ Ojeil ${ }^{4}$, G Brucato ${ }^{2,4}$, RB Gil ${ }^{1}$, LS Kegeles ${ }^{2,4}$, M Laruelle ${ }^{2}$, M Slifstein ${ }^{1}$, A Abi-Dargham ${ }^{1}$
${ }^{1}$ Department of Psychiatry, Stony Brook University School of Medicine, Stony Brook, NY, USA.

${ }^{2}$ Department of Psychiatry, Columbia University College of Physicians and Surgeons, New York, NY, USA.

${ }^{3}$ Department of Nuclear Medicine, University of Amsterdam, Amsterdam, The Netherlands.

${ }^{4}$ New York State Psychiatric Institute, New York, NY, USA. 